\title{
Total phenolic content and antioxidant and anticholinesterase activities of medicinal plants from the State's Cocó Park (Fortaleza-CE, Brazil)
}

Teor de fenóis totais e atividades antioxidante e anticolinesterase de plantas medicinais do Parque Estadual do Cocó (Fortaleza-CE, Brasil)

Contenido total de fenoles y actividades antioxidantes y anticolinesterasas de plantas medicinales en el Parque Estatal Cocó (Fortaleza-CE, Brasil)

\begin{abstract}
The State's Cocó Park in the city of Fortaleza-CE present mainly a mangrove flora and include landscape and medicinal plants. The aim of this study is determining the total phenol content, antioxidant activity against the free radical DPPH and the inhibition of the enzyme acetylcholinesterase (AChE) in ethanolic extracts of 30 medicinal plants and thus assess which plants have potential against Alzheimer's Disease. The plants rich in phenolic compounds with amounts ranging from $297.46 \pm 26.94$ to $599.30 \pm 17.08 \mathrm{mg}$ GAE/g plant extract, which showed greater antioxidant activities (with $\mathrm{IC}_{50}$ against $\mathrm{DPPH}$ radical from $3.44 \pm 0.16$ to $3.73 \pm 0.12 \mu \mathrm{g} \mathrm{mL}^{-1}$ ) and higher acetylcholinesterase inhibiting power $\left(\mathrm{IC}_{50}<20 \mu \mathrm{g} \mathrm{mL} \mathrm{m}^{-1}\right)$ were Anacardium occidentale, Ceiba pentandraLaguncularia racemosa, Mangifera indica, Myracrodrum urundeuva and Terminalia catappa. Then, these species and their constituents are recommended for more specific studies related to Alzheimer's Disease.
\end{abstract}

Keywords: Cocó State Park; Medicinal plants; Antioxidant activity; Anticholinesterase activity.

\section{Resumo}

O Parque Estadual do Cocó na cidade de Fortaleza-CE apresenta uma flora principalmente constituída de manguezais e inclui plantas decorativase plantas medicinais. O objetivo deste estudo é determinar o teor de fenóis totais a atividade antioxidante contra o radical livre DPPH e a inibição da enzima acetilcolinesterase (AChE) em extratos etanólicos de 30 espécies de plantas medicinais e assim avaliar quais plantas têm potencial contra a doença de Alzheimer. As plantas ricas em compostos fenólicos com teores superiores variando de 297,46 $\pm 26,94$ a 599,30 \pm $17,08 \mathrm{mg} \mathrm{GAE} / \mathrm{g}$ extrato vegetal, que apresentaram maiores atividades antioxidantes (com $\mathrm{IC}_{50}$ contra o radical DPPH de 3,44 $\pm 0,16$ a $3,73 \pm 0,12 \mu \mathrm{g} \mathrm{mL} \mathrm{mL}^{-1}$ ) e poder inibidor da acetilcolinesterase $\left(\mathrm{IC}_{50}<20 \mu \mathrm{g} \mathrm{mL}^{-1}\right.$ ) foram Anacardium occidentale, Ceiba pentandra, Laguncularia racemosa, Mangifera indica, Myracrodrum urundeuva e Terminalia catappa. Então, essas espécies e seus constituintes são recomendados para estudos mais específicos relacionados à Doença de Alzheimer. 
Palavras-chave: Parque Estadual do Cocó; Plantas medicinais; Atividade antioxidante; Atividade anticolinesterásica.

\section{Resumen}

El Parque Cocó del Estado en la ciudad de Fortaleza-CE presenta principalmente una flora de manglar e incluye plantas paisajísticas y medicinales. El objetivo de este estudio es determinar el contenido total de fenol, la actividad antioxidante frente al radical libre DPPH y la inhibición de la enzima acetilcolinesterasa (AChE) en extractos etanólicos de 30 especies medicinales y así evaluar qué plantas tienen potencial contra la enfermedad de Alzheimer. Las plantas ricas en compuestos fenólicos con cantidades que van desde $297.46 \pm 26.94$ a 599.30 \pm 17.08 mg GAE/g de extracto vegetal, que mostraron mayor actividad antioxidante (con $\mathrm{IC}_{50}$ contra el radical DPPH de $3.44 \pm 0.16$ a $3.73 \pm 0.12 \mu \mathrm{g} \mathrm{mL}^{-1}$ ) y superiores El poder inhibidor de la acetilcolinesterasa $\left(\mathrm{IC}_{50}<20 \mu \mathrm{g} \mathrm{mL}^{-1}\right.$ ) fueron Anacardium occidentale, Ceiba pentandra, Lagucularia racemosa, Mangifera indica, Myracrodrum urundeuva y Terminalia catappa. Luego, estas especies y sus constituyentes se recomiendan para estudios más específicos relacionados con la enfermedad de Alzheimer.

Palabras clave: Parque Estatal Cocó; Plantas medicinales; Actividad antioxidante; Actividad anticolinesterasa.

\section{Introduction}

The park bordering the Cocó river occupies an environmental conservation area containing 1,571.29 hectares, making it the largest natural park in an urban area in North/Northeast Brazil and the fourth in Latin America. Consisting mainly of mangroves, the park is a haven for the city's fauna. Being considered a kind of natural nursery for mollusks, crustaceans, fish, reptiles, birds and mammals, mainly Callithrix jacchus (Sousa \& Santos, 2016)). The State's Cocó Park besides offering leisure and tourist attractions, gives the opportunity for the elaboration of scientific researches.

Oxidative stress is an imbalance of free radicals and antioxidants in the body, which occurs naturally and plays a role in the aging process and it is related to many diseases such as cardiovascular diseases, acute and chronic kidney disease, neurodegenerative diseases, macular degeneration, biliary diseases, and cancer. There is a close relationship between oxidative stress, inflammation, and aging (Liguori et al., 2018). Oxidative stress is involved in the development of several human pathologies, such as hypertension, atherosclerosis, asthma, cancer, rheumatoid arthritis, cataracts, diabetes mellitus and degenerative diseases (sclerosis multiplies, Parkinson's disease and Alzheimer's disease) (Phaniendra et al, 2015). There is a lower incidence of degenerative diseases in populations that use diets composed of cereals, fruits, vegetables and natural foods, which are rich in antioxidant compounds, the most common being found are phenolic acids, flavonoids, vitamin C, vitamin E, selenium and carotenoids (Falco et al., 2016). Several studies have linked plant antioxidants with AChE inhibition and thus opened up several treatment options for AD (Akram \& Nawaz, 2017; Penido et al, 2017).

Drugs that have AChE inhibition as a mechanism of action are called anticholinesterase or indirectly cholinergics. $\mathrm{AChE}$ when blocked is unable to hydrolyze $\mathrm{ACh}$, thus, this neurotransmitter tends to remain active for a longer period in the synaptic cleft, a fact that increases cholinergic transmission. Drugs that block AChE in the peripheral nervous system (PNS), such as neostigmine, are used in atonic constipation, intestinal atony, urinary retention, myasthenia gravis and as an antagonist for myorelaxants. If the AChE inhibitor has an action in the central nervous system (CNS), such as Rivastigmine, it is useful in the treatment of dementia associated with Alzheimer's and Parkinson's diseases (Araujo et al., 2016).

Medicinal plants are relatively safe compared to synthetic drugs, according to the World Health Organization (WHO) it is estimated that about $80 \%$ of people worldwide depend on herbal medicines. These drugs are even used to treat neurological disorders associated with AChE regulation (Patel et al, 2018). Thus, this study aims to determine the total phenolic content, antioxidant activity and the inhibition of the enzyme acetylcholinesterase of medicinal plants present in the State's Cocó Park in Fortaleza, Ceará and elaborate a bibliographic survey on the activities reported for plants, to try to correlate with the activities determined in order to discover new herbal agents with potential to be used in the treatment of AD. 


\section{Methodology}

\section{Plant extracts}

The collection of plant material was carried out at State's Cocó Park in Fortaleza-CE in 2018 and the samples were from specific parts of each plant species according to popular use. All samples were placed in plastic bags and transported to the Laboratory of Chemistry of Natural Products at the State University of Ceará (UECE) where exsiccates were prepared, following the botanical criteria of drying and cataloging (Matos, 1988), then they were deposited in the Prisco Bezerra herbarium of the Federal University of Ceará (UFC) with exsiccate numbers shown in Table 1.

Table 1. Plant species, exsiccate numbers, coordinates and part used.

\begin{tabular}{|c|c|c|c|}
\hline Plants & Exsiccate & Coordinators WGS84 & Used part \\
\hline $\begin{array}{l}\text { Anacardium } \\
\text { occidentale }\end{array}$ & EAC 63659 & Lat.: -3.74486, Long.: -38.48616 & Stem bark \\
\hline Annona glabra & EAC 62371 & Lat.: $-3,74790$, Long.: -38.48692 & Leaves \\
\hline Bauhinia forficata & EAC 64239 & Lat.: -3.74429 , Long.: -38.48700 & Leaves \\
\hline $\begin{array}{l}\text { Brosimum } \\
\text { gaudichaudii }\end{array}$ & EAC 32315 & Lat.: -3.74404 , Long.: $-38,48760$ & Stem bark \\
\hline $\begin{array}{l}\text { Caesalpinia } \\
\text { pulcherrima }\end{array}$ & EAC 62367 & Lat.: -3.74408, Long.: -38.48754 & Leaves \\
\hline Cecropia pachistacia & EAC 38591 & Lat.: -3.74541 , Long.: -38.48837 & Leaves \\
\hline Ceiba pentandra & EAC 63664 & Lat.: -3.74420 , Long.: -38.48674 & Stem bark \\
\hline $\begin{array}{l}\text { Cenostigma } \\
\text { piramidale }\end{array}$ & EAC 62700 & Lat.: -3.74495 , Long.: -38.48497 & Leaves \\
\hline Cordia oncocalyx & EAC 63021 & Lat.: -3.74454 , Long.: -38.48732 & Stem bark \\
\hline $\begin{array}{l}\text { Couroupita } \\
\text { guianensis }\end{array}$ & EAC 62686 & Lat.: -3.74461 , Long.: -38.48694 & Leaves \\
\hline Crateva tapia & EAC 63060 & Lat.: -3.74541 , Long.: -38.48837 & Leaves \\
\hline Erythrina velutina & EAC 63666 & Lat.: -3.74403 , Long.: -38.48686 & Leaves \\
\hline Genipa americana & EAC 38580 & Lat.: -3.74627 , Long.: -38.48848 & Leaves \\
\hline Geoffroea spinosa & EAC 64414 & Lat.: -3.74994 , Long.: -38.48473 & Leaves \\
\hline Guazuma ulmifolia & EAC 62729 & Lat.: -3.74398 , Long.: -38.48601 & Leaves \\
\hline Handroanthus & & Lat.: -3.74514 , Long.: -38.48586 & Stem bark \\
\hline imperginosus & EAC 63062 & & \\
\hline Hymenaea & & Lat.: -3.74501, Long.: -38.48594 & Stem bark \\
\hline stigonocarpa & EAC 63406 & & \\
\hline Laguncularia & & Lat.: -3.74870 , Long.: -38.48467 & Leaves \\
\hline racemosa & EAC 38597 & & \\
\hline Libidibia ferrea & EAC 63016 & Lat.: -3.74402 , Long.: -38.48685 & Fruit \\
\hline Mangifera indica & EAC 63407 & Lat.: -3.74521 , Long.: -38.48544 & Leaves \\
\hline Mimosa tenuiflora & EAC 63667 & Lat.: -3.74413 , Long.: -38.48737 & Stem bark \\
\hline Moringa oleifera & EAC 62368 & Lat.: -3.74394 , Long.: -38.48672 & Leaves \\
\hline $\begin{array}{l}\text { Myracrodruon } \\
\text { urundueva }\end{array}$ & EAC 62695 & Lat.: -3.74426, Long.: -38.48664 & Stem bark \\
\hline Spondias mombim & EAC 63061 & Lat.: -3.74474 , Long.: -38.48680 & Leaves \\
\hline Syzygium cumini & EAC 63665 & Lat.: -3.74738 , Long.: -38.48745 & Leaves \\
\hline Talisia esculenta & EAC 64242 & Lat.: -3.74548 , Long.: -38.48396 & Seeds \\
\hline Tapirira guianensis & EAC 64238 & Lat.: -3.74462 , Long.: -38.48782 & Leaves \\
\hline Terminalia catappa & EAC 63657 & Lat.: -3.74786 , Long.: -38.48496 & Leaves \\
\hline Tocoyena formosa & EAC 64413 & Lat.: -3.74425 , Long.: -38.48655 & Leaves \\
\hline Ziziphus joazeiro & EAC 64241 & Lat.: -3.74744 , Long.: -38.48844 & Leaves \\
\hline
\end{tabular}

Source: Authors.

A license to do the collection of plants from the Cocó Park was given by Secretary of the Environment of the State Government of Ceará. 
To obtain the ethanol extracts, 50 grams of dry sample (oven at $60{ }^{\circ} \mathrm{C}$ ) were added to glass vessels containing $200 \mathrm{~mL}$ of ethyl alcohol (96\%). The samples were left for 10 days, then the resulting solution was filtered and concentrated on a rotary evaporator under pressure at $60{ }^{\circ} \mathrm{C}$ to evaporate the ethanol, then placed in a water bath to dry completely.

\section{Total phenol content}

The determination of the total phenol content was carried out using the Folin-Ciocalteu method described by Sousa et al. (2007). For each extract, $7.5 \mathrm{mg}$ was dissolved in $10 \mathrm{~mL}$ of P.A. methanol (99.8\%) using an ultrasonic bath, then transferred quantitatively to a $25 \mathrm{~mL}$ volumetric flask and the final volume was made up with methanol. A $100 \mu \mathrm{L}$ aliquot of this solution was transferred to a $10 \mathrm{~mL}$ volumetric flask with $500 \mu \mathrm{L}$ of the Folin-Ciocalteu reagent and stirred for 30 seconds, $6 \mathrm{~mL}$ of distilled water and $2 \mathrm{~mL}$ of $\mathrm{Na}_{2} \mathrm{CO}_{3}(15 \%)$ were added, stirring the mixture for more 60 seconds and the final volume was filled with distilled $\mathrm{H}_{2} \mathrm{O}$, the solution was kept at rest for 2 hours in a dark place. The white reagent was conducted under the same conditions. All determinations were made in triplicate. The same procedure was used to prepare the calibration standard curve $\left(y=0,127 x+0,011, R^{2}=0,995\right)$ obtained with 0 a $4 \mu \mathrm{g} . \mathrm{mL}^{-1}$ gallic acid solutions. The absorbances from the several concentrations were obtained in the UV-Vis (Genesys 10S UV-Vis Thermo Scientic) at $750 \mathrm{~nm}$. The results were determined by interpolation of the data with the gallic acid calibration standard equation and expressed in terms of mg GAE/g sample extract.

\section{Determination of antioxidant activity}

The determination of antioxidant capacity was carried out according to the free radical DPPH (2,2 diphenyl-1-pricrylhydrazil) methodology proposed by Yepez et al. (2002), with some modifications. A $6.5 \times 10^{-5} \mathrm{~mol} \mathrm{~L}^{-1}$ DPPH methanolic solution was prepared by diluting $1.3 \mathrm{mg}$ of radical in $50 \mathrm{~mL}$ of methanol PA (Neon 99.8\%) in a volumetric flask. Then, the DPPH solution was read and corrected to have a wavelength between 0.600 and $0.700 \mathrm{~nm}$. The extracts were initially solubilized to prepare a stock solution with a concentration of $10,000 \mathrm{ppm}$ ( $15 \mathrm{mg}$ of the extract in $1.5 \mathrm{~mL}$ of methanol), afterwards, the stock solution was diluted in the respective concentrations of 5,000, 1,000, 500, 100, 50, 10 and 5 ppm. After dilutions, $1.9 \mathrm{~mL}$ of the $6.5 \times 10^{-5} \mathrm{~mol} \mathrm{~L}^{-1} \mathrm{DPPH}$ solution and $0.1 \mathrm{~mL}$ of the sample solution from each dilution were placed in test tubes to react. For the positive control, quercetin was used in the same concentrations and the negative control consisted of $0.1 \mathrm{~mL}$ of methanol with $1.9 \mathrm{~mL}$ of the DPPH solution. The test was maintained in the absence of light for 30 minutes and then the reading was performed on the UV-Vis spectrophotometer (Genesys 10S UV-Vis Thermo Scientic), at a wavelength of 515 $\mathrm{nm}$. All procedures were performed in triplicate. The percentage of DPPH free radical inhibition by extracts at different concentrations was calculated by expressing the scavenging index percentage $(\mathrm{IV} \%)$ : $\mathrm{SI} \%=\left(\mathrm{Abs}_{\mathrm{DPPH}}-\mathrm{Abs}_{\mathrm{Amostra}} / \mathrm{Abs}_{\mathrm{DPPH}}\right) \mathrm{x}$ 100.

The effective concentration to inhibit $50 \%$ of the free radical DPPH $\left(\mathrm{CE}_{50}\right)$ was obtained with the aid of the Excel 2019 software, using the sample concentration values and the scavenging index (SI\%). Dispersion graphs were generated whose linear equations were used to obtain the values of the mean and standard deviation. For comparison purposes, a calibration curve was constructed with different percentages of the quercetin flavonoid, which has high antioxidant activity in the DPPH free radical to calculate the $\mathrm{IC}_{50}$ of the extracts.

\section{Determination of anti-AChE activity}

AChE inhibition activity test was performed using the spectrophotometric method of Ellman et al. (1961), modified by Trevisan et al. (2003) for 96-well flat-bottomed microplates. For the preparation of the test plate, the following solutions were used per well: $25 \mu \mathrm{L}$ of acetylthiocholine iodide $\left(15 \mathrm{mmol} \mathrm{L}^{-1}\right), 125 \mu \mathrm{L}$ of 5,5'-dithiobis- [2-nitrobenzoic] in the Tris/HCl 
solution (50 mmol L-1 $\mathrm{pH}=8$ ), with $0.1 \mathrm{~mol} \mathrm{~L}^{-1} \mathrm{NaCl}$ and $0.02 \mathrm{~mol} \mathrm{~L}^{-1} \mathrm{MgCl}_{2} \cdot 6 \mathrm{H}_{2} \mathrm{O}$. (3 mmol L $\mathrm{m}^{-1}$, DTNB), $50 \mu \mathrm{L}$ of the Tris/ $\mathrm{HCl}$ solution $\left(50 \mathrm{mmol} \mathrm{L}^{-1}, \mathrm{pH}=8\right.$ ), with $0.1 \%$ of bovine serum albumin (BSA), $25 \mu \mathrm{L}$ of the extract sample dissolved in ethanol $\left(2 \mathrm{mg} \mathrm{mL}^{-1}\right)$ and diluted 10 times in the Tris/ $\mathrm{HCl}$ solution $\left(50 \mathrm{mmol} \mathrm{L}^{-1}, \mathrm{pH}=8\right)$ to obtain a final concentration of 0.2 mg. $\mathrm{mL}^{-1}$. The absorbance was measured at $405 \mathrm{~nm}$ in the microplate reader (BIOTEK ELX 800, software Gen5 V2.04.11), for 30 seconds. Then, $25 \mu \mathrm{L}$ of the enzyme acetylcholinesterase $\left(0.25 \mathrm{U} \cdot \mathrm{mL}^{-1}\right)$ was added and the absorbance was measured per minute until the total of 25 minutes of incubation of the enzyme. As a blanc control, the reactive mixture excluding the sample, and for the positive control, the alkaloid physostigmine was used. The values referring to the natural colorings of the extracts were extinguished from the analysis. The percentage of acetylcholinesterase inhibition was calculated by comparing the reaction rates (substrate hydrolysis) of the samples in relation to the blank (considered total AChE activity, 100\%). The dilutions of the samples and the positive standard started from the mother solution with a concentration of $20 \mathrm{mg} \mathrm{mL}^{-1}$ and were: $200 \mu \mathrm{g} \mathrm{mL}^{-1}, 100 \mu \mathrm{g} \mathrm{mL}^{-1}, 50 \mu \mathrm{g} \mathrm{mL}^{-1}, 25 \mu \mathrm{g} \mathrm{mL}^{-1}, 12,5 \mu \mathrm{g} \mathrm{mL}^{-1}, 6,25 \mu \mathrm{g} \mathrm{mL}^{-1}, 3,12 \mu \mathrm{g} \mathrm{mL}^{-1}, 1,56 \mu \mathrm{g} \mathrm{mL}^{-1}$, and 0,78 $\mu \mathrm{g} \mathrm{mL}{ }^{-1}$. After normalizing the data, a non-linear regression curve test was performed using the Graph Pad Prism v5.01 statistical program to obtain the final results.

\section{Statistical analysis}

The statistical analysis was performed using the Graph Pad Prism v5.01 program, where the data were submitted to the one-way test of variance analysis (ANOVA) to determine the statistical differences followed by the multiple comparison between pairs by the Tukey test, considering significant values at $\mathrm{P}<0.05$. To analyze the correlation between the data, Pearson's correlation coefficient was used in the Microsoft Excel 2019 software, which measures the degree of linear correlation between two quantitative variables.

\section{Results and Discussion}

In the State's Cocó Park, 30 species of medicinal plants were collected and the plant part was chosen according to the popular use. About the families the most prevalent was Fabaceae (8), followed by Anacardiaceae (5), Rubiaceae (2) and Combretaceae (2). The activities of the plants are displayed in Table 2. The most common use of plants is for gastrointestinal diseases as diarrhea and dysentery (12/30), following the treatment of dermatitis, wounds (healing) and mycosis (9/30); for inflammation and infections - 7 plants; respiratory tract diseases such as bronchitis, asthma and cough - 6 plants; diabetes - 5 plants and for cancer or anti-tumor Annona glabra, Cordia oncocalyx and Moringa oleifera. An ethnobotanical survey with High School students about medicinal plants in Maranguape-Ceará showed that the most cited therapeutic indications were related to diseases of the respiratory, digestive and circulatory systems (Castro et al, 2021). In another study 22 plants from Caxias city of Maranhão State, cited by the population, being mainly indicated for poor digestion, insomnia, hypertension, cough, flu and inflammation (Silva et al, 2021). Then, these informations confirm that the medicinal plants present in Cocó Park are representatives of the popular use of plants for medicinal purposes. In general, these diseases can be related to oxidative stress and to the action of the acetylcholinesterase enzyme, then phenolic compounds can act in several pathogens and strengthen the immune system, contributing to treat Alzheimer's disease. 
Table 2. Species of medicinal plants present in Cocó State's Park, common name and popular medicinal indication.

\begin{tabular}{|c|c|c|c|}
\hline Species (Family) & Common Name & Popular use & References \\
\hline $\begin{array}{l}\text { Anacardium occidentale L. } \\
\text { (Anacardiaceae) }\end{array}$ & Cajueiro & $\begin{array}{l}\text { Inflammation of the gums and throat, } \\
\text { toothache, asthma, bronchitis, arthritis } \\
\text { and diabetes. }\end{array}$ & Silva \& Almeida, 2013. \\
\hline Annona glabra L. (Annonaceae) & $\begin{array}{l}\text { Araticum do } \\
\text { Brejo }\end{array}$ & $\begin{array}{l}\text { Chronic bronchitis, cancer, parasites and } \\
\text { insects. }\end{array}$ & Cochrane et al., 2008. \\
\hline Bauhinia forficata Link (Fabaceae) & Mororó & $\begin{array}{l}\text { Diabetes, infections, processes } \\
\text { inflammatory and pain. }\end{array}$ & López \& Santos, 2015. \\
\hline $\begin{array}{l}\text { Brosimum gaudichaudii Trécul } \\
\text { (Moraceae) }\end{array}$ & Inharé & Skin spots and dermatitis. & Agra et al., 2008. \\
\hline $\begin{array}{l}\text { Caesalpinia pulcherrima (L.) SW } \\
\text { (Fabaceae) }\end{array}$ & $\begin{array}{l}\text { Flamboyant } \\
\text { Mirim }\end{array}$ & $\begin{array}{l}\text { Infections, fevers, malaria, bronchitis, } \\
\text { diarrhea and dysentery. }\end{array}$ & Kumbhare et al., 2012. \\
\hline $\begin{array}{l}\text { Cecropia pachystachya Trécul } \\
\text { (Urticaceae) }\end{array}$ & Torém & $\begin{array}{l}\text { Respiratory infections, diabetes and } \\
\text { gonorrhea. }\end{array}$ & Souza et al., 2014. \\
\hline $\begin{array}{l}\text { Ceiba pentandra (L.) Gaertn. } \\
\text { (Malvaceae) }\end{array}$ & Paineira & $\begin{array}{l}\text { Bronchitis, asthma, cough, skin disease, } \\
\text { dysentery, gonorrhea, eye diseases, } \\
\text { arthritis and fever. }\end{array}$ & Loganayaki et al., 2013. \\
\hline $\begin{array}{l}\text { Cenostigma pyramidale (Tul.) E. Gagnon } \\
\& \text { G. P. Lewis (Fabaceae) }\end{array}$ & Catingueira & $\begin{array}{c}\text { Inflammation, bronchitis, expectorant, } \\
\text { depurative, intestinal infections and } \\
\text { fever. }\end{array}$ & Silva et al., 2015. \\
\hline $\begin{array}{l}\text { Cordia oncocalyx Allemão } \\
\text { (Boraginaceae) }\end{array}$ & $\begin{array}{l}\text { Pau Branco do } \\
\text { Sertão }\end{array}$ & $\begin{array}{l}\text { Analgesic, antioxidant, anti-inflammatory } \\
\text { and anti-tumor. }\end{array}$ & Guimarães et al., 2013. \\
\hline $\begin{array}{l}\text { Couroupita guianensis Aubl. } \\
\text { (Lecythidaceae) }\end{array}$ & $\begin{array}{l}\text { Abricó de } \\
\text { Macaco }\end{array}$ & Stomach pains and skin diseases. & Kumar et al., 2011. \\
\hline Crateva tapia L. (Capparaceae) & Trapiá & $\begin{array}{l}\text { Respiratory tract infections, dysentery } \\
\text { and fever. }\end{array}$ & Sharma et al., 2013. \\
\hline Erythrina velutina Willdenow (Fabaceae) & Mulungu & Stress, insomnia, anxiety and depression. & Palumbo et al., 2016. \\
\hline Genipa americana L. (Rubiaceae) & Jenipapo & Diabetes, fever and liver disease. & França, 2017. \\
\hline Geoffroea spinosa Jacq. (Fabaceae) & Marizeira & Menstrual disorders and anemia. & Souza et al., 2015. \\
\hline Guazuma ulmifolia Lam. (Sterculiceae) & Mutamba & $\begin{array}{c}\text { Gastrointestinal and cardiovascular } \\
\text { diseases. }\end{array}$ & Pereira et al., 2019. \\
\hline $\begin{array}{l}\text { Handroanthus impetiginosus (Mart. ex } \\
\text { DC.) Mattos (Bignoniaceae) }\end{array}$ & Ipê Roxo & Diabetes, ulcers and syphilis. & Fonseca et al., 2017. \\
\hline $\begin{array}{l}\text { Hymenaea stigonocarpa Mart. ex Hayne } \\
\text { (Fabaceae) }\end{array}$ & $\begin{array}{l}\text { Jatobá do } \\
\text { Cerrado }\end{array}$ & Anti-inflammatory, gastritis and ulcers. & Orsi et al., 2014. \\
\hline $\begin{array}{l}\text { Laguncularia racemosa (L.) C. F. } \\
\text { Gaertn. (Combretaceae) }\end{array}$ & Mangue Branco & Fever and diarrhea. & Bandaranayake, 2002. \\
\hline $\begin{array}{l}\text { Libidibia ferrea (Mart. ex Tul.) } \\
\text { L.P.Queiroz (Fabaceae) }\end{array}$ & Jucazeiro & $\begin{array}{c}\text { Bacterial, healing and anti-inflammatory } \\
\text { infections. }\end{array}$ & Kobayashi et al., 2015. \\
\hline Mangifera indica L. (Anacardiaceae) & Mangueira & $\begin{array}{l}\text { Constipation, cough, hiccup, bleeding, } \\
\text { wounds, ulcers, hemorrhoids, dysentery } \\
\text { and burns. }\end{array}$ & Parvez, 2016. \\
\hline $\begin{array}{l}\text { Mimosa tenuiflora (Mart.) Benth. } \\
\text { (Fabaceae) }\end{array}$ & Jurema Preta & Burns, acne and skin problems. & Cruz et al., 2016. \\
\hline Moringa oleífera Lam. (Moringaceae) & Moringa & $\begin{array}{l}\text { Ulcer, inflammation, wounds, heart } \\
\text { problem, cancer, stroke, obesity, anemia } \\
\text { and liver damage. }\end{array}$ & Aja et al., 2014 \\
\hline $\begin{array}{l}\text { Myracrodruon urundeuva M. Allemão) } \\
\text { (Anacardiaceae) }\end{array}$ & $\begin{array}{l}\text { Aroeira do } \\
\text { Sertão }\end{array}$ & Diarrhea, dysentery and how to heal. & Freitas et al., 2018. \\
\hline Spondias mombim L. (Anacardiaceae) & Cajazeira & Diarrhea, dysentery and herpes. & Silva et al., 2014. \\
\hline Syzygium cumini (L.) Skeel (Myrtaceae) & Azeitona Preta & Diabetes mellitus & $\begin{array}{l}\text { Cartaxo-Furtado et al., } \\
2017 .\end{array}$ \\
\hline $\begin{array}{l}\text { Talisia esculenta (A. St.-Hil.) Radlk } \\
\text { (Sapindaceae) }\end{array}$ & Pitombeira & $\begin{array}{l}\text { Diarrhea, dehydration, low back pain and } \\
\text { kidney problems. }\end{array}$ & Guarim Neto et al., 2003. \\
\hline $\begin{array}{l}\text { Tapirira guianensis Aublet } \\
\text { (Anacardiaceae) }\end{array}$ & Pau Pombo & Leprosy, diarrhea and syphilis. & Rodrigues et al., 2017. \\
\hline Terminalia catappa L. (Combretaceae) & Castanholeira & $\begin{array}{l}\text { Gastritis, urinary tract infection, } \\
\text { dermatitis, hepatitis, diarrhea and fever. }\end{array}$ & Silva et al., 2015. \\
\hline $\begin{array}{l}\text { Tocoyena formosa } \\
\text { (Cham. \& Schltdl.) (Rubiaceae) }\end{array}$ & Jenipapo Bravo & $\begin{array}{c}\text { Cough, cystitis, torsion, rheumatism, } \\
\text { kidney problems, cardiac, liver and } \\
\text { cystitis. }\end{array}$ & Souza et al., 2013. \\
\hline Ziziphus joazeiro Mart. (Rhamnaceae) & Juazeiro & $\begin{array}{l}\text { Dermatitis, mycosis, dandruff, } \\
\text { constipation, stomatitis, gastric ulcers, } \\
\text { poor digestion and mouthwash. }\end{array}$ & Silva et al., 2011. \\
\hline
\end{tabular}


Source: Authors.

Cholinergic stimulation by administration of acetylcholinesterase inhibitors, enhances intestinal antimicrobial activity and prevents systemic dissemination of pathogenic bacteria, and the mechanism is a crucial pathway between neural and immune systems that acts at the mucosal interface to protect the host against invading pathogens (Al-Barazie et al., 2018).

Phenolic compounds including flavonoids are well-known antioxidants and presenting also many other important bioactivities for human health, curing and preventing many diseases, such as antibacterial, anti-cancer, cardioprotective, immunostimulant and anti-inflammatory and skin protective effect from UV radiation (Tungmunnithum et al., 2018).

The antioxidant and anticholinesterase activities of plant extracts may reveal the potential for the treatment of Alzheimer's Disease (AD). Bigueti, Lellis and Dias (2018) demonstrated that the intake of antioxidant substances contributed to the reduction of the disease incidence, and can be used as an alternative therapy for the treatment of the disease.

Previous studies (Achkar et al., 2014; Silva et al., 2010) have shown that the total phenol content above $100 \mu \mathrm{g} \mathrm{mL}$ is already considered a high value in plant extracts, and in the ethanolic extracts of thirty plants from Cocó Park, 21 entered in this relation. Taking into account the best results in the present work, it is observed that ten species demonstrated antioxidant activity correlating linearly with the phenol content: A. occidentale, C. pentandra, H. stigonocarpa, L. racemosa, L. férrea, M. indica, M. tenuiflora, M. urundeuva, S. mombim, T. cattapa, whose total phenol content ranges from $297.46 \pm 26.94 \mu \mathrm{g} \mathrm{mL}^{-1}$ (S. mombim) to $599.30 \pm 17.08 \mu \mathrm{g} \mathrm{mL}^{-1}$ (M. tenuiflora) - with antioxidant activities with $\mathrm{IC}_{50}$ against DPPH radical ranging from $3.44 \pm 0.16$ to $3.73 \pm 0.12 \mu \mathrm{g} \mathrm{mL} L^{-1}$, respectively (Table 3 ). Such a result is expected, since phenolic compounds have a high antioxidant capacity. Therefore, many medicinal plants present in Cocó Park are sources of antioxidant compounds. 
Table 3. Content of Total Phenols (TP), Antioxidant Activity (DPPH) and Antiacetylcholinesterase (AChEI) of the ethanolic extracts of medicinal plants from Cocó's State Park.

\begin{tabular}{|c|c|c|c|}
\hline Plants & $\begin{array}{l}\text { TP (mg GAE/g } \\
\text { extract) }\end{array}$ & $\begin{array}{c}\text { IC }_{50} \text { DPPH } \\
\left(\mu \mathrm{gmL}^{-1}\right)\end{array}$ & $\begin{array}{c}\text { AChEI } \\
\left(\mu \operatorname{gmL}^{-1}\right)\end{array}$ \\
\hline Anacardium occidentale & $452.53^{c} \pm 15.15$ & $4.04^{\mathrm{d}} \pm 0,12$ & $15.09^{1} \pm 0.04$ \\
\hline Annona glabra & $70.87^{\circ} \pm 15.97$ & $163.61^{\mathrm{s}} \pm 3,53$ & $15.6^{\mathrm{m}} \pm 0.15$ \\
\hline Bauhinia forficata & $229.22^{\mathrm{g}} \pm 19.87$ & $12.56^{\mathrm{i}} \pm 0,33$ & $29.2^{\mathrm{x}} \pm 1.87$ \\
\hline Brosimum gaudichaudii & $146.11^{1} \pm 13.21$ & $14.01^{\mathrm{j}} \pm 0,96$ & $23.97^{\mathrm{r}} \pm 0.02$ \\
\hline Caesalpinia pulcherrima & $100.61^{\mathrm{n}} \pm 14.46$ & $17.58^{\mathrm{k}} \pm 0,95$ & $13.14^{\mathrm{h}} \pm 0.01$ \\
\hline Cecropia pachistacia & $151.36^{1} \pm 3.03$ & $11.84^{\mathrm{h}} \pm 0,13$ & $29.78^{\mathrm{x}} \pm 0.08$ \\
\hline Ceiba pentandra & $352.58^{\mathrm{e}} \pm 9.22$ & $4.19^{\mathrm{d}} \pm 0,16$ & $15.87^{\mathrm{n}} \pm 0.02$ \\
\hline Cenostigma piramidale & $414.70^{\mathrm{d}} \pm 21.48$ & $12.64^{\mathrm{i}} \pm 0,11$ & $7.04^{\mathrm{b}} \pm 0.04$ \\
\hline Cordia oncocalyx & $71.73^{\circ} \pm 3.29$ & $72.00^{\circ} \pm 0,59$ & $26.55^{\mathrm{u}} \pm 0.16$ \\
\hline Couroupita guianensis & $213.47^{\mathrm{h}} \pm 6.61$ & $24.20^{1} \pm 1,12$ & $24.15^{\mathrm{s}} \pm 0.07$ \\
\hline Crateva tapia & $114.61^{\mathrm{n}} \pm 1.52$ & $90.67^{p} \pm 1,36$ & $12.04^{\mathrm{f}} \pm 0.04$ \\
\hline Erythrina velutina & $134.73^{\mathrm{m}} \pm 6.61$ & $68.55^{\circ} \pm 4,64$ & $23.20^{\mathrm{q}} \pm 0.02$ \\
\hline Genipa americana & $33.25^{\mathrm{p}} \pm 1.52$ & $605.93^{\mathrm{u}} \pm 40,70$ & $27.81^{\mathrm{v}} \pm 0.03$ \\
\hline Geoffroea spinosa & $188.10^{\mathrm{j}} \pm 6.61$ & $139.50^{r} \pm 2,58$ & $28.10^{\mathrm{w}} \pm 0.02$ \\
\hline Guazuma ulmifolia & $73.49^{\circ} \pm 5.25$ & $89.00^{p} \pm 3,17$ & $49.90^{\mathrm{y}} \pm 0.09$ \\
\hline Handroanthus imperginosus & $74.37^{\circ} \pm 4.01$ & $38.08^{n} \pm 1,74$ & $12.63^{\mathrm{g}} \pm 0.21$ \\
\hline Hymenaea stigonocarpa & $404.20^{\mathrm{d}} \pm 10.50$ & $5.82^{\mathrm{e}} \pm 0,26$ & $23.98^{\mathrm{r}} \pm 0.11$ \\
\hline Laguncularia racemosa & $408.57^{d} \pm 14.46$ & $6.32^{\mathrm{f}} \pm 0.32$ & $10.95^{\mathrm{c}} \pm 0.02$ \\
\hline Libidibia ferrea & $394.58^{d} \pm 10.61$ & $3.30^{c} \pm 0.18$ & $29.15^{\mathrm{x}} \pm 0.07$ \\
\hline Mangifera indica & $493.44^{b} \pm 13.89$ & $7.29^{\mathrm{g}} \pm 0.38$ & $11.71^{\mathrm{d}} \pm 0.02$ \\
\hline Mimosa tenuiflora & $599.30^{\mathrm{a}} \pm 17.08$ & $3.44^{\mathrm{c}} \pm 0.16$ & $29.34^{\mathrm{x}} \pm 0.09$ \\
\hline Moringa oleifera & $97.11^{\mathrm{n}} \pm 11.14$ & $191.00^{t} \pm 3.08$ & $20.76^{\mathrm{p}} \pm 0.08$ \\
\hline Myracrodruon urundueva & $432.20^{c} \pm 5.46$ & $3.09^{\mathrm{b}} \pm 0.06$ & $13.35^{\mathrm{i}} \pm 0.00$ \\
\hline Spondias mombim & $297.46^{\mathrm{f}} \pm 26.94$ & $3.73^{\mathrm{d}} \pm 0.12$ & $28.10^{\mathrm{w}} \pm 0.02$ \\
\hline Syzygium cumini & $178.48^{\mathrm{k}} \pm 5.25$ & $11.92^{\mathrm{h}} \pm 0.23$ & $14.10^{\mathrm{j}} \pm 0.16$ \\
\hline Talisia esculenta & $71.74^{\circ} \pm 3.03$ & $14.94^{\mathrm{j}} \pm 0.44$ & $12.60^{\mathrm{g}} \pm 0.11$ \\
\hline Tapirira guianensis & $200.35^{\mathrm{i}} \pm 21.21$ & $13.20^{\mathrm{j}} \pm 0.69$ & $14.32^{\mathrm{k}} \pm 0.05$ \\
\hline Terminalia catappa & $447.07^{c} \pm 21.85$ & $6.09^{f} \pm 0.12$ & $11.82^{\mathrm{e}} \pm 0.12$ \\
\hline Tocoyena formosa & $140.86^{1} \pm 9.94$ & $29.73^{\mathrm{m}} \pm 1.42$ & $24.18^{t} \pm 0.03$ \\
\hline Ziziphus joazeiro & $189.85^{\mathrm{j}} \pm 10.93$ & $123.04^{\mathrm{q}} \pm 1.23$ & $17.15^{\circ} \pm 0.19$ \\
\hline Physostigmine & - & - & $1.15^{\mathrm{a}} \pm 0.05$ \\
\hline Quercetin & - & $1.32^{\mathrm{a}} \pm 0.05$ & - \\
\hline
\end{tabular}

All tests were performed in triplicate and the results were expressed as mean \pm standard deviation; ${ }^{1}$ milligram Equivalent to Gallic Acid per gram of extract; ${ }^{2}$ Effective concentration to inhibit $50 \%$ of the free radical DPPH $(2,2-$ diphenyl - $1-$ picryl - hydrazil); ${ }^{3}$ Inhibitory concentration for $50 \%$ of acetylcholinesterase activity. (-) Tests not performed. Source: Authors.

The results obtained in the inhibition of AChE activity were compared to that of the alkaloid physostigmine, which was the first discovered natural inhibitor. Santos et al. (2018), determined the anticholinesterase activity of extracts and fractions from 54 plants and classified the action according to the $\mathrm{IC}_{50}$ values as: high potency $\left(\mathrm{IC}_{50}<20 \mu \mathrm{g} \mathrm{mL}^{-1}\right)$; moderate power $(20$ $\left.<\mathrm{IC}_{50}<200 \mu \mathrm{g} \mathrm{mL}^{-1}\right)$ and low power $\left(200<\mathrm{IC}_{50}<1000 \mu \mathrm{g} \mathrm{mL}^{-1}\right)$. Evaluating the results obtained in the AChE inhibition test, it is observed that 15 plants presented results below $20 \mu \mathrm{g} \mathrm{mL}-1$, therefore with a high inhibition power, they are: A. occidentale, 
A. glabra, C. pulcherrima, C. pentandra, C. pyramidale, C. tapia, H. impetiginosus, L. racemosa, M. indica, M. urundeuva, S. cumini, T. esculenta, T. guianensis, T. catappa and Z. joazeiro.

In the correlation of the total phenol content with AChE enzyme inhibiting action, considering the 15 best results, but only six species that presented $\mathrm{IC}_{50}$ between 11 and $14 \mu \mathrm{g} \mathrm{mL}-1$ correlate linearly with the levels of phenols: $C$. pulcherrima, M. indica, M. urundeuva, S. cumini, T. guianensis and T. catappa.

A weak correlation was obtained between the total phenolic content and AChE inhibition activity and these results are corroborated by studies by Barbosa Filho et al. (2006), who showed many other types of compounds exerting this activity. They report that out of 260 chemical compounds studied with AChE inhibiting action, only 51 were phenolic compounds (18 coumarins, 14 flavonoids, 13 benzenoids, 3 stilbenes, 2 lignans and 1 quinoid), however alkaloids were the majority class with 139 compounds. Another study reported by Santos et al. (2018) on the anti-acetylcholinesterase activity of plant species extracts, it was concluded that out of 54 plant species belonging to 29 different families, 36 compounds were identified, of which 16 showed potent inhibition, being superior to galantamine ( 1 terpene, 2 coumarins and 13 alkaloids) and another 20 compounds with lower potency (phenolic and flavonoid acids). Observing that the phenolic compounds did not show prominent AChE inhibition results, and the alkaloids represent the class with the highest potency in the evaluation.

Similarly, previous work with plants from living pharmacies, Morais et al. (2013) deduced that there was no linear correlation between $\mathrm{AChE}$ enzyme inhibition and the mean inhibition concentration of the DPPH radical - $\mathrm{CE}_{50}$ from the extracts of the tested plants.

Other studies have also shown that the mechanism of action of AChEIs is not limited to their effects on the neuron-toneuron transmission involving acetylcholine but extends to their protective effects of a cell against free radical toxicity as well as increased production of antioxidants. A diet rich in polyphenols and polyunsaturated fatty acids helps boost the production of the brain's stem cells -neurogenesis- and strengthens their differentiation in different types of neuron cells. These results give support to the hypothesis that a diet made up of foods rich in antioxidant substances could delay the onset of DA or even slow down its evolution (Valente et al., 2009).

Thus, agents that combine antioxidant properties with the inhibition of AChE are expected to find usefulness in the management of AD (Tabet, 2006).

\section{Conclusion}

In conclusion, of the 30 species studied 6 stood out taking into account high levels of phenols and better antioxidant and acetylcholinesterase inhibition effects: A. occidentale, C. pentandra, L. racemosa, M. indica, M. urundeuva, T. catappa. Therefore, these plants can be considered the most promising as sources of phenolic compounds to be used in the treatment of Alzheimer's disease, due to their relevant action of inhibiting free radicals and the enzyme acetylcholinesterase.

\section{References}

Achkar, M. T., Novaes, G. M., Silva, M. J. D., \& Vilegas, W. (2013). Propriedade antioxidante de compostos fenólicos: Importância na dieta e na conservação de alimentos. Revista da Universidade Vale do Rio Verde, 11(2), 398-406. http://dx.doi.org/10.5892/ruvrd.v11i2.398406

Agra, M. F., Silva, K. N., Basílio, I. J. L. D., Freitas, P. F., \& Barbosa-Filho, J. M. (2008). Survey of medicinal plants used in the region Northeast of Brazil. Revista Brasileira de Farmacognosia, 18(3), 472-508. https://dx.doi.org/10.1590/S0102-695X2008000300023

Aja, P. M., Nwachukwu, N., Ibiam, U. A., Igwenyi, I. O., Offor, C. E., \& Orji, U.O. (2014). Chemical constituents of Moringa oleifera leaves and seeds from Abakaliki, Nigeria. American Journal of Phytomedicine and Clinical Therapeutics, 2(3), 310-321. https://www.imedpub.com/articles/chemical-constituentsof-moringa-oleiferaleaves-and-seeds-from-abakaliki-nigeria.pdf

Akram, M., \& Nawaz, A. (2017). Effects of medicinal plants on Alzheimer's disease and memory deficits. Neural Regeneration Research, 12(4), 660-670. http://dx.doi.org/10.4103/1673-5374.205108 
Al-Barazie, R. M., Bashir, G. H., Qureshi, M. M., Mohamed, Y. A., Al-Sbiei, A., Tariq, S., Lammers, W. J., Al-Ramadi, B. K., \& Fernandez-Cabezudo M. J. (2018). Cholinergic activation enhances resistance to oral Salmonella infection by modulating innate immune defense mechanisms at the intestinal barrier. Frontiers in immunology, 9(19), 551. https://doi.org/10.3389/fimmu.2018.00551

Araújo, C. R. M., Santos, V. L. A., \& Gonsalves, A. A. (2016). Acetylcholinesterase - AChE: a pharmacological interesting enzyme. Revista Virtual de Química 8(6), 1818-1834. http://dx.doi.org/10.21577/1984-6835.20160122

Bandaranayake, W. M. (2002). Bioactivities, bioactive compounds and chemical constituents of mangrove plants. Wetlands Ecology and Management, 10(6), 421-452. http://dx.doi.org/10.1023/A:1021397624349

Barbosa, F. G., Lima, M. A. S., Braz-Filho, R. \& Silveira, E. R. (2006). Iridoid and phenylethanoid glycosides from Lippia alba. Biochemical Systematics and Ecology, 34(11), 819-821. http://dx.doi.org/10.1016/j.bse.2006.06.006

Bigueti, B. C. P., Lellis, J. Z. \& Dias, J. C. R. (2018). Essential nutrients in the prevention of Alzheimer's disease. Revista Ciências Nutricionais Online, 2(2), 18-25. https://www.unifafibe.com.br/revistasonline/arquivos/cienciasnutricionaisonline/sumario/62/13042018180525.pdf

Cartaxo-Furtado, N. A. D. E. O., Sampaio, T. O., Xavier, M. A., Medeiros, A. D. D. E. \& Pereira, J. V. (2015). Phytochemical profile and determination of the antimicrobial activity of Syzygium cumini (L.) Skeels (Myrtaceae) against oral microorganisms. Revista Brasileira de Plantas Medicinais, 17(43), 1091-1096. https://dx.doi.org/10.1590/1983-084x/14_153

Castro, M. A. de, Bonilla, O. H., Pantoja, L. D. M., Mendes, R. M. S., Edson-Chaves, B. \& Lucena, E. M. P. de (2021). Research, Society and Development, v. 10, n. 3, e8910313008. DOI: 10.33448/rsd-v10i3.13008.

Cochrane, C. B., Nair, P., Raveendran, K., Melnick, S. J., Resek, A. P., \& Ramachandran, C. (2008). Anticancer effects of Annona glabra plant extracts in human leukemia cell lines. Anticancer Research, 28(1), 965-972. https://ar.iiarjournals.org/content/anticanres/28/2A/965.full.pdf

Cruz, M. P., Andrade, C. M. F., Silva, K. O., Souza, E. P., Yatsuda, R., \& Marques, L. M. (2016). Antinoceptive and anti-inflammatory activities of the ethanolic extract, fractions and flavones isolated from Mimosa tenuiflora (Willd.) Poir (Leguminosae). Plos One, 11(3), e0150839. http://dx.doi.org/10.1371/journal.pone.0150839

Ellman, G. L., Courtney, K. D., Andres, V. J., \& Featherstone, R. M. (1961). A new and rapid colorimetric of acetylcholinesterase determination of acetylcholinesterase activity. Biochemical Pharmacology, 7(2), 88-95. https://dx.doi.org/10.1016/0006-2952(61)90145-9

Falco, A., Cukierman, D. S., Hauser-Davis, R. A., \& Rey, N. A. (2016). Alzheimer's disease: etiological hypotheses and treatment perspectives: Etiological hypotheses and treatment perspectives. Química Nova, 39(1), 63-80. http://dx.doi.org/10.5935/0100-4042.20150152

Fonseca Filho, I. C., Bomfim, B. L. S., Farias, J. C., Vieira, F. J., \& Barros, R. F. M. (2017). Pau-d'arco-roxo (Handroanthus Impetiginosus (Mart. Ex Dc.) Mattos): Conhecimento e uso madeireiro em comunidades rurais do nordeste do Brasil. Gaia Scientia, 11(2), 57-70. https://dx.doi.org/10.22478/ufpb.1981$1268.2017 \mathrm{v} 11 \mathrm{n} 2.34878$

França, F. V. (2017). Phytochemical study and antioxidant activity of ethanol extract from Genipa americana. Revista Mundi Saúde e Biológicas, 2(2), 1-12. http://dx.doi.org/10.21575/25254766msb2017vol2n2393

Freitas, R. F., Lima, P. R. A., Pimentel, M. A., \& Queiroz, P. R. (2018). Phytochemical profile, microbiological assay and toxicity against saline artemia from Myracrodruon urundeuva. Biota Amazônia, 8(3), 24-27. http://dx.doi.org/10.18561/2179-5746/biotaamazonia.v8n3p24-27

Guarim Neto, G., Santana, S.R., \& Silva, J. V. B. (2003). Botanical repertoire of "Pitombeira" (Talisia esculenta (A. St.-Hil.) Radlk. - Sapindaceae). Acta Amazônica, 33(2), 237-242. https://dx.doi.org/10.1590/1809-4392200332242

Guimarães, I. P., Coelho, M. F. B., Azevedo, \& R. A. B. (2013). Pau Branco (Cordia oncocalyx Allemão) - Boraginaceae: Endemic tree of the Caatinga. Revista Verde de Agroecologia e Desenvolvimento Sustentável, 8(5), 31-39. https://www.gvaa.com.br/revista/index.php/RVADS/article/view/2114

Kobayashi, Y. T. S., Almeida, V. T., Bandeira, T., Alcântara, B. N., Silva, A. S. B., Barbosa, W. L. R., Silva, P. B., Monteiro, M. V. B., \& Almeida, M. B. (2015). Phytochemical evaluation and healing potential of the ethanolic extract of the fruits of Jucá (Libidibia ferrea) in wistar rats. Brazilian Journal of Veterinary Research and Animal Science, 52(1), 34-40. https://dx.doi.org/10.11606/issn.1678-4456.v52i1p34-40

Kumar, C. S., Naresh, G., Sudheer, V., \& Veldi, N. (2011). A short review on therapeutic uses of Couroupita guianensis Aubl. International Research Journal of Pharmaceutical and Applied Sciences, 1(1), 105-108. https://scienztech.org/irjpas/article/view/281/224

Kumbhare, M. R., Sivakumar, T., Udavant, P. B., Dhake, A. S., \& Surana, A. R. (2012). In vitro antioxidant activity, phytochemical screening, cytotoxicity and total phenolic content in extracts of Caesalpinia pulcherrima (Caesalpiniaceae) pods. Pakistan Journal of Biological Sciences, 15(7), 325-332. https://dx.doi. org/10.3923/pjbs.2012.325.332

Loganayaki, N., Siddhuraju, P., \& Manian, S. (2013). Antioxidant activity and free radical scavenging capacity of phenolic extracts from Helicteres isora L. and Ceiba pentandra L. Journal of Food Science and Technology, 50(4), 687-695. https://dx.doi.org/10.1007/s13197-011-0389-x

López, R. E. S., \& Santos, B. C. (2015). Bauhinia forficata Link (Fabaceae). Revista Fitos, 9(3), 161-252. https://dx.doi.org/10.5935/2446-4775.20150018

Liguori, I., Russo, G., Curcio, F., Bulli, G., Aran, L., Della-Morte, D., Gargiulo, G., Testa, G., Cacciatore, F., Bonaduce, D., \& Abete, P. (2018). Oxidative stress, aging, and diseases. Clinical Interventions in Aging, 13, 757-772. https://dx.doi.org/10.2147/CIA.S158513

Matos, F. J. A. (2009). Introdução à fitoquímica experimental (3a ed.). Edições UFC.

Morais, S. M., Lima, K. S. B., Siqueira, S. M. C., Cavalcanti, E. S. B., Souza, M. S. T., Menezes, J. E. S. A., \& Trevisan, M. T. S. (2013). Correlation between antiradical, anti-acetylcholinesterase activities and total phenol content of medicinal plant extracts from live pharmacies. Revista Brasileira de Plantas Medicinais, 15(4), 575-582. https://dx.doi.org/10.1590/S1516-05722013000400014 
Orsi, P. R., Bonamin, F., Severi, J. A., Santos, R. C., Vilegas, W., Hiruma-Lima, C. A., \& Stasi, L. C. D. (2012). Hymenaea stigonocarpa Mart. Ex Hayne: A Brazilian medicinal plant with gastric and duodenal anti-ulcer and antidiarrheal effects in experimental rodent models. Journal of Ethnopharmacology, 143(1), 81-90. https://dx.doi.org/10.1016/j.jep.2012.06.001

Palumbo, C. F. G., Gardin, N. E., \& Nakamura, M. U. (2015). Erythrina mulungu Mart. Ex Benth and Erythrina velutina Willd. - Pharmacological aspects and anthroposophical perspective of Brazilian plants. Arte Médica Ampliada, 36(4), 152-161. http://abmanacional.com.br/wp-content/uploads/2017/06/36-4Erythrina-mulungu-e-Erythrina-velutina.pdf

Parque Ecológico do rio Cocó. (2010) https://www.semace.ce.gov.br/2010/12/08/paque-ecologico-do-rio-coco/ Access 14/04/2021

Parvez, G. M. M. (2016). Pharmacological activities of mango (Mangifera indica): A review. Journal of Pharmacognosy and Phytochemistry, 5(3), 1-7. https://www.phytojournal.com/archives/2016/vol5issue3/PartA/5-2-21-518.pdf

Patel, S. S., Raghuwanshi, R., Masood, M., Acharya, A., \& Jain, S. K. (2018). Medicinal plants with acetylcholinesterase inhibitory activity. Reviews in the Neurosciences, 29(5), 491-529. https://dx.doi.org/10.1515/revneuro-2017-0054

Penido, A. B., Morais, S. M., Ribeiro, A. B., Alves, D. R., Rodrigues, A. L. M., Santos, L. H., \& Menezes, J. E. S. A. (2017). Medicinal plants from northeastern Brazil against Alzheimer's disease. Evidence-Based Complementary and Alternative Medicine, $1,1753673$. https://dx.doi.org/10.1155/2017/1753673

Pereira, G. A., Araujo, N. M. P., Arruda, H. S., Farias, D. P., Molina, G., \& Pastore, G. M. (2019). Phytochemicals and biological activities of Mutamba (Guazuma ulmifolia Lam.): A review. Food Research International, 126, 108713. https://dx.doi.org/10.1016/j.foodres.2019.108713

Phaniendra, A., Jestadi, D. B., \& Periyasamy, L. (2014). Free radicals: Properties, sources, targets, and their implication in various diseases. Indian Journal of Clinical Biochemistry, 30(1), 11-26. https://dx.doi.org/10.1007/s12291-014-0446-0

Rodrigues, A., Guimarães, D., Konno, T., Tinoco, L., Barth, T., Aguiar, F., Lopes, N., Leal, I., Raimundo, J., \& Muzitano, M. (2017). Phytochemical study of Tapirira guianensis leaves guided by vasodilatory and antioxidant activities. Molecules, 22(2), 304-316. https://dx.doi.org/10.3390/molecules22020304

Santos, T. C., Gomes, T. M., Pinto, B. A. S., Camara, A. L., \& Paes, A. M. A. (2018). Naturally occurring acetylcholinesterase inhibitors and their potential use for Alzheimer's disease therapy. Frontiers in Pharmacology, 9, 1192. https://dx.doi.org/10.3389/fphar.2018.01192

Sharma, P., Patil, D., Patil, A. (2013). Crateva tapia Linn. - an important medicinal plant: A review of its traditional uses, phytochemistry and pharmacologiccal properties. International Journal of Pharmaceutical Sciences and Research, 4(2), 582-589. http://dx.doi.org/10.13040/IJPSR.0975$8232.4(2) .582-89$

Silva, A. E. S., \& Almeida, S. S. M. S. (2013). Análise fitoquímica das cascas do caule do cajueiro (Anacardium occidentale L. - Anacardiaceae) Estação Científica (Unifap), 3(2), 81-88. https://periodicos.unifap.br/index.php/estacao/article/view/1169/annav3n2.pdf

Silva, F. D. B., Sales, M. A. G., Sá, O. R. M., Santana, G. M., Deus, M. S. M., Sousa, J. M. C. E., Ferreira, P. M. P., \& Peron, A. P. (2015). Cytotoxic, genotoxic and cytoprotective potential of aqueous extracts from Caesalpinia pyramidalis Tul., Caesalpinia ferrea Mart. and Caesalpinia pulcherrima Sw. Revista Brasileira de Biociências, 13(2), 101-109. http://www.ufrgs.br/seerbio/ojs/index.php/rbb/article/view/3252/1279

Silva, G. A., Brito, N. J. N., Santos, E. C. G., López, J. A., \& Almeida, M. G. (2014). Spondias genus: botanical aspects, chemical composition and pharmacological potential. Revista de Biologia, Farmácia e Manejo Agrícola, 10(1), 27-41.

Silva, L. P., Angelis, C. D., Bonamin, F., Kushima, H., Mininel, F. J., Santos, L. C., Delella, F. K., Felisbino, S. L., Vilegas, W., \& Rocha, L. R. M. (2015). Terminalia catappa L.: A medicinal plant from the caribbean pharmacopeia with anti-helicobacter pylori and antiulcer action in experimental rodent models. Journal of Ethnopharmacology, 15(159), 285-295. http://dx.doi.org/10.1016/j.jep.2014.11.025

Silva, M. L. C., Costa, R. S., Santana, A. S., \& Koblitz, M. G. B. (2010). Phenolic compounds, carotenoids and antioxidant activity in plant products. Semina: Ciências Agrárias, 31(3), 669-682. http://dx.doi.org/10.5433/1679-0359.2010v31n3p669

Silva, T. C. L., Almeida, C. C. B. R., Veras Filho, J., Peixoto Sobrinho, T. J. S., Amorim, E. L. C., Costa, E. P., \& Araújo, J. M. (2011). Antioxidant and antimicrobial activities of Ziziphus joazeiro Mart. (Rhamnaceae): Comparative evaluation between bark and leaves. Journal of Basic and Applied Pharmaceutical Sciences, 2(32), 193-199. https://rcfba.fcfar.unesp.br/index.php/ojs/article/view/344/342

Silva, A. F. L. da \& Barros, L. A. A. (2021). Evaluation of practices for the use of medicinal plants in the City of Caxias-MA. Research, Society and Development, [S. l.], v. 10, n. 4, p. e10010413832, 2021. DOI: 10.33448/rsd-v10i4.13832.

Sousa, C. M. M., Silva, H. R., Vieira-Júnior, G. M., Ayres, M. C. C., Costa, C. L. S., Araújo, D. S., Cavalcanti, L. C. D., Barros, E. D. S., Araújo, P. B. M., Brandão, M. S., \& Chaves, M. H. (2007). Total phenolics and antioxidant activity of five medicinal plants. Química Nova, 30(2), 351-355. https://dx.doi.org/10. 1590/S0100-40422007000200021

Sousa, É. N. C. \& Santos, S. A. (2016). O processo de implantação do Parque Estadual do Cocó, Fortaleza (CE): conflitos e perspectivas. Revista de Geociências do Nordeste, 2, 781-790. https://periodicos.ufrn.br/revistadoregne/article/view/10526

Souza, D. O., Tintino, S. R., Figueiredo, F. G., Borges, M. C. M., Braga, M. F. B. M., Felipe, C. F. B., Costa, J. G. M., Coutinho, H. D. M., Menezes, I. R. A., \& Kerntopf, M. R. (2014). Antibacterial and modulating activity of Cecropia pachystachya Trécul on the action of aminoglycosides. Revista Cubana de Plantas Medicinales, 19(1), 121-132. https://www.medigraphic.com/pdfs/revcubplamed/cpm-2014/cpm143a.pdf

Souza, R. K. D., Mendonça, A. C. A. M., \& Silva, M. A. P. (2013). Ethnobotanical, phytochemical and pharmacological aspects of Rubiaceae species in Brazil. Revista Cubana de Plantas Medicinales, 18(1), 140-156. https://www.medigraphic.com/pdfs/revcubplamed/cpm-2013/cpm131p.pdf 
Research, Society and Development, v. 10, n. 5, e7510514493, 2021

(CC BY 4.0) | ISSN 2525-3409 | DOI: http://dx.doi.org/10.33448/rsd-v10i5.14493

Souza, R. O. S., Assreuy, A. M. S., Madeira, J. C., Chagas, F. D. S., Parreiras, L. A., Santos, G. R. C., Mourão, P. A. S., \& Pereira, M. G. (2015). Purified polysaccharides of Geoffroea spinosa barks have anticoagulant and antithrombotic activities devoid of hemorrhagic risks. Carbohydrate Polymers, 124, 208215. https://dx.doi.org/10.1016/j.carbpol.2015.01.069

Tabet, N. (2006). Acetylcholinesterase inhibitors for Alzheimer's disease: Anti-inflammatories in acetylcholine clothing. Age and Ageing, 35(4), 336-338. https://dx.doi.org/10.1093/ageing/afl 027

Trevisan, M. T. S., Macedo, F. V. V., Van De Meent, M. H. M., Rhee I. K., \& Verpoorte, R. (2003). Seleção de plantas com atividade anticolinesterase para tratamento da doença de Alzheimer. Química Nova. 26(3), 301-304. https://dx.doi.org/10.1590/S0100-40422003000300002

Tungmunnithum, D., Thongboonyou, A., Pholboon, A., \& Yangsabai, A. (2018). Flavonoids and other phenolic compounds from medicinal plants for pharmaceutical and medical aspects: An overview. Medicines, 5(3), 93. https://dx.doi.org/10.3390/medicines5030093

Valente, T., Hidalgo, J., Bolea, I., Ramirez, B., Anglès, N., Reguant, J., Morelló, J., Gutiérrez, C., \& Boada, M. (2009). A diet enriched in polyphenols and polyunsaturated fatty acids, LMN diet, induces neurogenesis in the subventricular zone and hippocampus of adult mouse brain. Journal of Alzheimer's Disease, 18(4), 849-865. https://dx.doi.org/10.3233/JAD-2009-1188

Yepez, B., Espinosa, M., López, S., \& Bolaños, G. (2002). Producing antioxidant fractions from herbaceous matrices by supercritical fluid extraction. Fluid Phase Equilibria, 194(197), 879-884. https://dx.doi.org/10.1016/S0378-3812(01)00707-5 